\title{
Constant-Fatigue Performance of Different Polyurethane Foams for Sitting Purposes
}

\author{
Samet DEMIREL*ํㅜ, Busra ERGUN TUNA
}

Karadeniz Technical University, Faculty of Forest, Forest Industry Engineering, Trabzon, TURKEY

*Corresponding Author: sdemirel@ktu.edu.tr

Received Date: 05.10.2018

Accepted Date: 14.06.2019

Abstract

Aim of study: The target of this study was measuring the changes in IFD firmness and thickness values after constant-fatigue loading on the polyurethane (PUR) foams, with six different densities and two different categories, produced in Trabzon/Turkey.

Material and Method: The foams were firstly exposed to indentation force deflection (IFD) and constant-fatigue tests based on ASTM D3574 standard. Then, the final IFD values of the foams were determined after loading and the changes in IFD values were reported.

Main results: Results indicated that increasing the density of foam in normal category decreased the IFD loss rate in foam firmness. However, this was vice versa for the soft foams. The support factors of normal foams raised as density increased after constant-fatigue loading, however; the support factors of soft foams decreased as the density increased. All foams used in this study indicated a thickness loss lower than $10 \%$ after constant-fatigue loading and, no visual failure was detected on the appearances of foams.

Highlights: It is important to note that when using a soft foam in a sofa frame, it technically shows opposite behavior both in IFD loss and support factor values under constant-fatigue loading compared to normal foam.

Keywords: Foam, IFD, Constant Fatigue, Loading, Firmness, Support Factor.

\section{Oturma Amaçlı Farklı Özellikteki Poliüretan Süngerlerin Sürekli- Yorulma Performansları}

Öz

Çalışmanın amacı: Bu çalışmanın amacı, Trabzon / Türkiye'de üretilen altı farklı yoğunlukta ve iki farklı kategoride olan poliüretan süngerlere uygulanan sürekli yorulma yüklemesi sonrası IFD sertlik ve kalınlık değerlerinde meydana gelen değişimleri incelemektir.

Materyal ve Metod: ASTM D3574 standardı baz alınarak süngerler ilk olarak IFD sertlik testine ve sürekli-yorulma testlerine tabi tutulmuştur. Daha sonra, süngerlerin sürekli yükleme sonrası nihai IFD sertlik değerleri ölçülmüştür. Süngerlerin IFD sertlik değerlerindeki değişimler rapor edilmiştir.

Sonuçlar: Normal kategorideki süngerlerin yoğunluğunun arttırılması sünger sertliğini gösteren IFD kayıp oranını azalmasına sebep olmuştur. Ancak, bu durum yumuşak kategorideki süngerler için tam tersidir. Bununla birlikte, normal süngerlerin destek faktörü değerleri, sürekli-yorulma yüklemesinden sonra yoğunluk arttıkça artmış, yumusak süngerler için yoğunluk arttıkça azalmıştır. Bu çalışmada kullanılan tüm süngerler, sürekli-yorulma yüklemesinden sonra, \% 10'dan daha az bir kalınlık kaybı göstermiş olup, süngerlerin görünüşlerinde görsel bir bozulma tespit edilmemiş̧ir.

Önemli vurgular: Koltuk üretiminde yumuşak bir sünger kullanılacağı zaman, sürekli yorulma yüklemesi altında yumuşak süngerlerin normal süngerlere göre teknik olarak tamamen zit bir davranış gösterdiğini bilmek önemli olacaktır.

Anahtar Kelimeler: Sünger, IFD, Sürekli Yorulma, Yükleme, Sertlik, Destek Faktörü.

\section{Introduction}

Polyurethane (PUR) foam is widely used in many field because of its enough compressive strength, good thermal resistance and fine sound absorption properties, lower thermal conductivity, and light weight (Gama, Silva, Carvalho, Ferreira \& Barros-Timsen 2017; Kumar and Kaur 2017). PUR foam is an upholstering material that is also widely used in the furniture industry due to its favorable properties such as price flexibility, durability, non-allergic 
qualities and favorable properties such as not allowing to grow mold or fungus in its structure (De Mello, Pezzin \& Amico, 2009).

There is a wide variety of PUR foams, which are sorted in three categories: hard, semi-rigid (normal) and flexible (soft). Foams are widely used in market because they can be produced in different density, color and different pore sizes as well as being light and cheap. Especially in manufacturing of upholstered furniture and beds, they have completely seized the place of traditional materials such as horse hair, cotton balls, and rubber foams (De Mello et al., 2009). Approximately $95 \%$ of the world furniture manufacturing sector and $80 \%$ of the bed manufacturing sector either use PUR foams partially or completely (Lal and Raman, 1992). In upholstered furniture, foams are used in different parts of the frame with another materials such as spring, padding, fabric, stretching along with steel materials which are really important for the performances of furniture. The positions of foams in upholstered furniture are shown in Fig. 1.

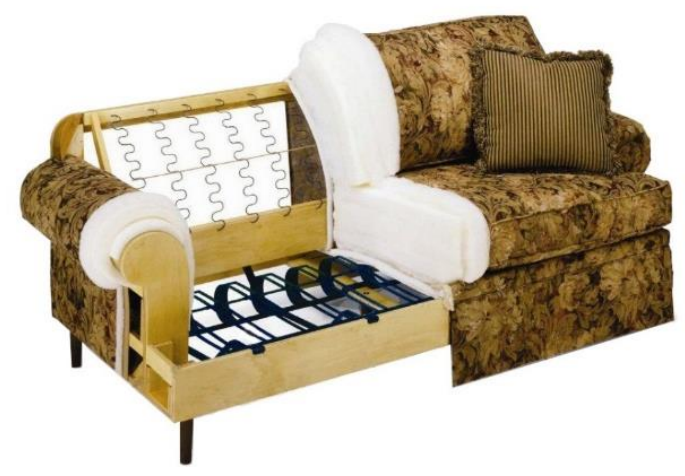

Figure 1. The positions of foams in upholstered furniture

It is mostly believed that mechanical properties are important for PUR foams used in furniture (Li, Yang, Li, Jiang \& Liang, 2018). In progress of time, the fabric in an upholstered sofa become loose. Indeed, it is not the fabric which deform. It is the foam which deforms in time. Therefore, it is always crucial to check the mechanical performance of a foam in an upholstered frame under a specified load (Fig. 1).

Some specifications of PUR foams are vitally important demonstrators of foam performance in the terms of comfort, support and durability. One of the specifications is the foam density which is the material quantity in the unit, unitized in kilograms per cubic meter $\left(\mathrm{kg} / \mathrm{m}^{3}\right)$ or in pounds per cubic foot (pcf). Density is one of the parameter which affects mechanical properties of foams (Aliha, Linul, Bahmani, \& Marsavina, 2018). Greater density stands for more durability in foam, which means more expensive at the same time because higher density foam contains more PUR. High-density foams (made of pure PUR without additive) meet seating better, provide higher support and more comfort and, they last longer (Cooperation Extension Furniture n.d.). The other demonstrator is the firmness of foam which is measuring the surface sense of the foam being independent from foam density. If foam is too firm or too soft, there may be a variety of problems in its processing. Being firmer of foam does not mean the foam with greater durability and longer service time. The important thing is that firmness of foam should fit other physical properties (Birlik Sünger, 2013b). Although higher foam density come to a meaning of being firmer, density and firmness are two independent parameters (AFPF, 1996). Therefore, consumers can choose foams with low density and firm properties, while they can prefer foams with higher density and soft properties as well. However, there is a paradox in understanding this situation. Likewise in the study of Gök et al. (2012), it is reported that the firmness of a material is directly proportional to the density of the material. The higher density of the material refers to the higher firmness.

IFD firmness is a measurement carried out by applying pressure to foam up to $25 \%$ of its height (PFA, 2016). Sometimes a secondary IFD measurement is performed by compressing foam under load up to $65 \%$ of its height. This secondary measurement is used to determine the bottom support of foam. The rate of $65 \%$ IFD to $25 \%$ IFD is called as support factor. This factor ranges from 1.5 to 2.6. The greater the difference between $25 \%$ IFD and $65 \%$ IFD values, the greater support or the greater load carrying capacity for foam. Foams with a higher support factor have many advantages such as long-term service (PFA, 1994). 
Constant or cyclic loadings, as fatigue loading, is one of the way of seeing the actual foam performance in seating practices (Eckelman, 1998a, 1988b). Fatigue test measures strength and height loss of foam before and after the test by exposing it cyclic compression in a certain amount. Life span of a foam divers based on density of the foam, amount of load and amount of time at service (Gök et al., 2012). As a result of applying fatigue load to foam, physical strength and firmness loss can be observed (PFA, 1993). In addition, constant-fatigue tests represent the loads that people sit or lie on foams and measure loss of firmness at the end of those sitting and lying on activities. Additionally, constant-fatigue test shows how a foam loss its initial flexibility over time (Hager \& Craig, 1992; Hu, Tackett, Tor \& Zhang, 2016).

The studies on the strength and firmness of PUR foams are very limited and inadequate. In 1979, Society of Polyurethane Industry (SPI) and Polyurethane Foam Association (PFA) in United States started collaborating a study on measuring of foam fatigue property. In a marketing congress, Dr. Herman Stone 1982, presented a report that showed a progress in this topic. Then, Knight (1987) continued Herman Stone's study and conducted some research on fatigue properties of foams. In particular, Knight discovered some advancements on roller type dynamic fatigue test and investigated the correlation between the roller type dynamic fatigue test and the real field applications on foam fatigue. As a result, Knight (1987) observed that there is a perfect correlation between tests in laboratory conditions and results from real service area applications.

Tod, Smith \& Vongpaseuth (1998) pointed out the effects of sample dimension when determining the firmness of PUR foams. Accordingly, PUR foams were prepared in four different sizes and, IFD values were determined according to ASTM D3574 standards. As a result of the study, it was observed that the firmness values of the test specimens varied with different crosssectional areas of the test specimens. Therefore, it is inferred from the study that foam firmness foam is able to be tested in a similar manner with the service area.
Hager \& Craig (1992) different testing procedures, sampling, and loading on foam. They discussed the different profile properties of traditional and high performance of foams with similar density and $25 \%$ IFD. Based on the results, the strength of PUR foams was significantly influenced by testing procedure and type of foam.

Saha et al. (2005) studied effect of density on the compression behavior of polymeric foams. They investigated that maximum stress was mostly depend on density and microstructure of foam material.

Gök et al. (2012) studied on the foam firmness changes. Therefore PUR foams were subjected to four different cyclic loadings (50, $70,90,120 \mathrm{~kg}$ ) and these loads were applied 7000 times on the foams. The study showed that these four different loads did not made significant different fatigue effect on foam samples.

Demirel and Ergun Tuna (2019) investigated the cyclic fatigue performance of PUR foams. The foams were exposed to two different cyclic loading levels and IFD measurements were carried out before, between and after loadings. Results indicated that increasing foam density reduced $25 \%$ IFD loss in normal foams but insignificantly increased in soft foams. On the other hand, increasing foam density decreased $65 \%$ IFD loss both for normal and soft category foams.

In current study, ASTM D3574 standard was used for evaluating foam performance (ASTM, 2011). The reason using this standard is due to being generally accepted standard by international test organizations such as, Testresources (n.d.), The American Association of Laboratory Accreditation (A2LA) (n.d.), The Canadian Standards Council (n.d.), Materials Testing System Manufacturer American Company (ADMET) (n.d.), DDL test certification laboratory (n.d.), Zwick Roell test system company (n.d.), and IDM instruments (n.d.).

In this study, the relationship between foam density and firmness was evaluated to see the trend between those two. Beyond that it was mainly aimed to investigate the effects of constant-fatigue loading on foam performance. Accordingly, the first and last IFD firmness values of the foams were measured respectively; before and after 
constant-fatigue loading and the differences in thickness and firmness were calculated and interpreted.

\section{Materials and Methods Materials}

For this study, the test specimens of foam blocks with six different densities $(14,18,22$,
24, 28 and $32 \mathrm{~kg} / \mathrm{m}^{3}$ ) within two different categories of normal and soft specified were used, and the foams were obtained from one local foam producer, Gundogdu Furniture, of Eastern Karadeniz Region in Turkey. Typical views of foam were indicated in Fig. 2.

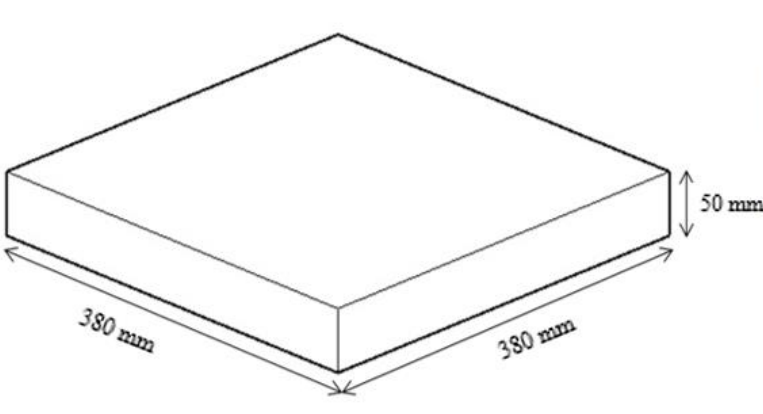

(a)

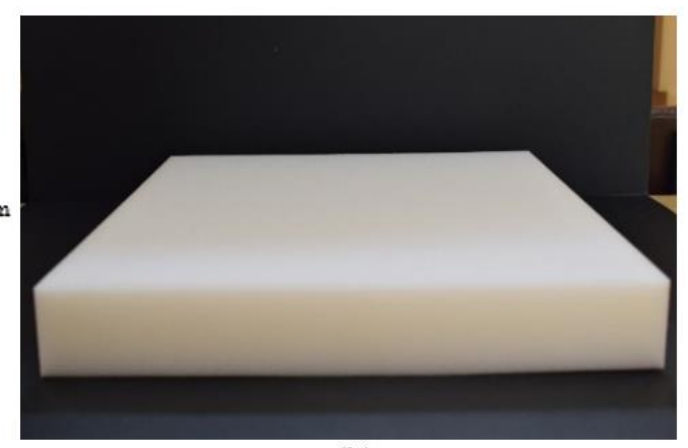

(b)

Figure 2. a) Dimensions of a foam, b) a foam before constant fatigue loading.

For each density group, five specimens were cut in the dimensions of $380 \times 380 \times 50$ $\mathrm{mm}$ specified in ASTM D3574 standard, and totally 30 foam sample tested. The foams were categorized into two types according to their firmness as normal foams and soft foams.

\section{Method of Constant Loading}

First, IFD firmness values of foams with the dimensions of $380 \times 380 \times 50 \mathrm{~mm}$ were determined, and then they were exposed to a

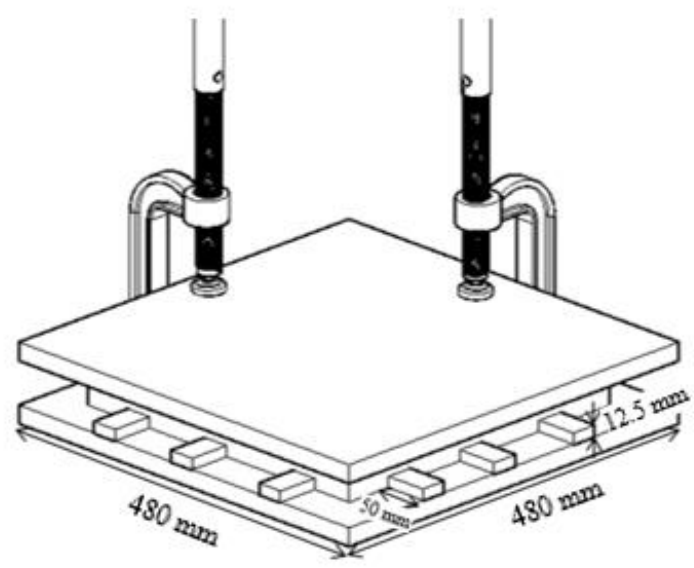

(a) constant-fatigue loading. Foams were compressed to $25 \%$ of their thickness (up to $75 \%$ compression) between plates and allowed to stand under this load for 22 hours. After 22 hours, the load on the foams was removed and thickness losses in the foams were measured. The last IFD firmness measurement was performed for these foams due to calculating IFD loss of foams. Fig. 3 shows a pressed foam between the plates during constant-fatigue loading.

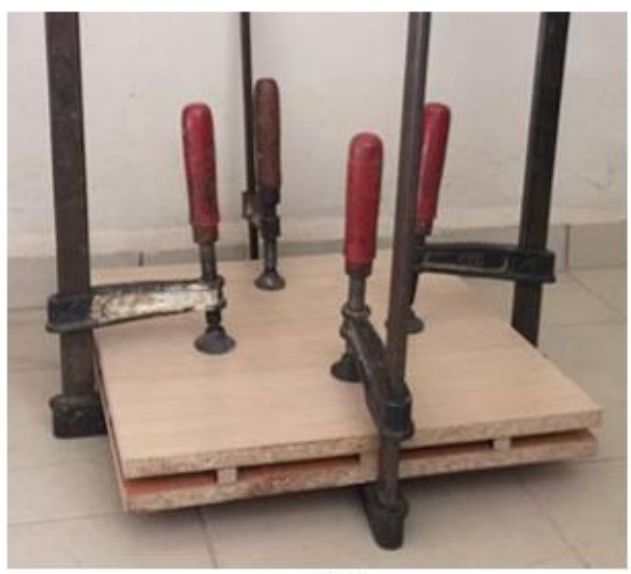

(b)

Figure 3. a) A representative view of foam compressed between the plates, b) a real view of foam compressed to a thickness of $25 \%$ between the plates 
As shown in Fig. 3, the foams were pressed to their thickness of $25 \%$ and subjected to constant-fatigue loading by using chocks with a thickness of $12.5 \mathrm{~mm}$ between two identical plates.

\section{Method of IFD Testing}

This test was carried out on MTS universal machine. A radial head with the diameter of $200 \mathrm{~mm}$ was used for loading. In Fig. 4a illustrates MTS universal machine.

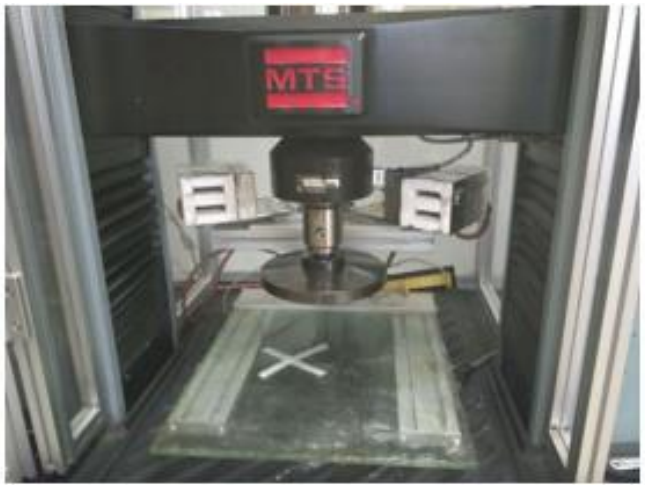

(a)

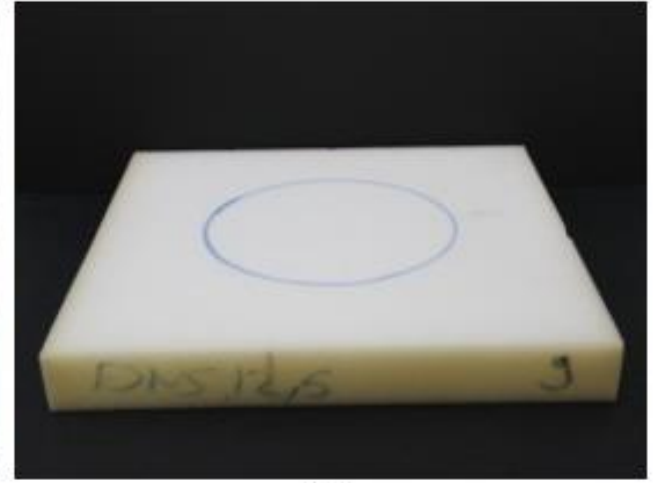

(b)

Figure 4. a) IFD Testing of a foam, b) Loading site marking after pre-compression before IFD test

Each foam was pre-compressed to $75 \%$ and relaxed for approximately 5 minutes before the IFD firmness test as specified in the standard. Meantime, the loading site on foam was marked as indicated in Fig. 4 b.

After $75 \%$ pre-compression, IFD test was employed on each foam. After IFD test was initiated, the loading was stopped at the compression level of $25 \%$ of foam thickness and waited for 60 seconds to record load value. Then loading was restarted until the compression level of $65 \%$ of foam thickness, the loading was stopped and waited for 60 seconds to determine the second load. After each waited 60 seconds, the loads were determined for $25 \%$ and $65 \%$ compressions. Fig. 5 indicates a typical representation of loading steps for $25 \%$ and $65 \%$ compression, respectively.

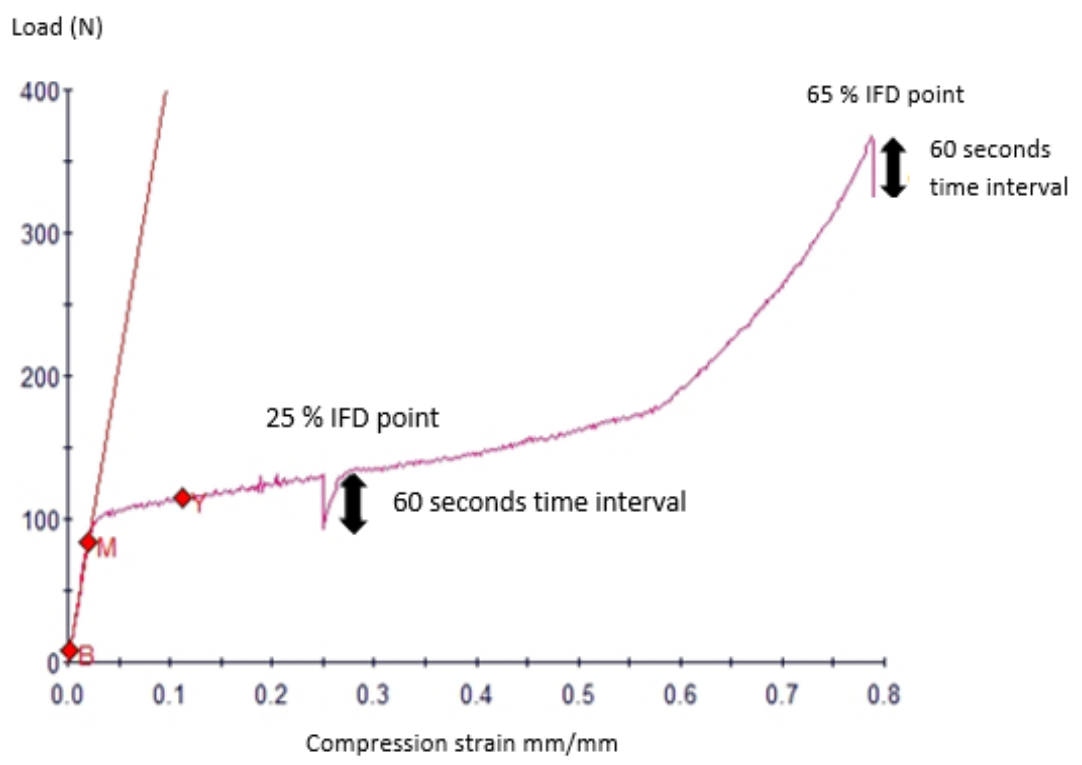

Figure $5.25 \%$ and $65 \%$ IFD loading steps 
While $25 \%$ IFD value provided information about material firmness, \% 65 IFD value provided support factor which is the ratio of the $65 \%$ IFD to the $25 \%$ IFD. The following equation was employed for the IFD loss values.

$F_{L}=\frac{\left(F_{0}-F_{f}\right)}{\left(F_{0}\right)} * 100$

Where:

$F_{L}=$ the loss value both at $\% 25$ and $\% 65$ IFD,

$F_{0}=$ the force both at $\% 25$ and $\% 65$ IFD before testing $(\mathrm{N})$,

$F_{f}=$ the force both at $\% 25$ and $\% 65$ IFD after testing $(\mathrm{N}$

The following equation was employed for the thickness loss values observed in foam samples after constant loading.

$F_{t}=\frac{\left(t_{0}-t_{f}\right)}{\left(t_{0}\right)} * 10$

Where:

$F_{t}=$ the $\%$ thickness loss,

$t_{0}=$ the first thickness of foam specimen (mm),

$t_{f}=$ the last thickness of foam specimen $(\mathrm{mm})$.

\section{Results and Discussion}

In current study, initial IFD firmness measurement, constant-fatigue test and final IFD firmness measurement were performed, respectively, for each foam group with 6 different densities and two different categories. Accordingly, constant-fatigue performance for each foam group was determined. The foam IFD values were calculated as the thickness loss was less than $10 \%$. If the thickness loss was more than 10 $\%$, it did not need to implement IFD test.

The mean IFD loss values of the each foam group acquired after constant-fatigue loading are summarized in Table 1. As shown in Table 1, mean IFD loss decreased as density increased from 14 to $28 \mathrm{~kg} / \mathrm{m}^{3}$ for the foams in normal category. However, mean IFD loss values increased as density increased from 24 to $32 \mathrm{~kg} / \mathrm{m}^{3}$ in soft foams. Additionally, all of the foam thickness loss values are less than 10 $\%$.

Table 1. Mean IFD loss values for foams exposed to constant fatigue test

\begin{tabular}{|c|c|c|c|c|}
\hline \multirow{2}{*}{$\begin{array}{c}\text { Foam } \\
\text { Category }\end{array}$} & \multirow{2}{*}{$\begin{array}{l}\text { Density } \\
\left(\mathrm{kg} / \mathrm{m}^{3}\right)\end{array}$} & \multirow{2}{*}{$\begin{array}{c}\text { Thickness } \\
\text { Loss } \\
(\mathrm{mm})\end{array}$} & \multicolumn{2}{|c|}{$\begin{array}{l}\text { IFD Loss } \\
\text { After Test }\end{array}$} \\
\hline & & & $25(\%)$ & $65(\%)$ \\
\hline \multirow{4}{*}{ Normal } & 14 & 2 & $\begin{array}{c}23.6 \mathrm{~B} \\
(7.1)\end{array}$ & $\begin{array}{c}42.2 \\
A^{*} \\
(3.2)^{* *} \\
\end{array}$ \\
\hline & 18 & 2 & $\begin{array}{c}16.6 \mathrm{~B} \\
(5.5)\end{array}$ & $\begin{array}{c}29.2 \mathrm{~A} \\
(3.3) \\
\end{array}$ \\
\hline & 22 & 3 & $\begin{array}{c}12.4 \mathrm{~A} \\
(2.7)\end{array}$ & $\begin{array}{c}16.8 \mathrm{~A} \\
(5.5)\end{array}$ \\
\hline & 28 & 2 & $\begin{array}{c}15.2 \mathrm{~A} \\
(2.2)\end{array}$ & $\begin{array}{l}17 \mathrm{~A} \\
(2.6)\end{array}$ \\
\hline \multirow{2}{*}{ Soft } & 24 & 2 & $\begin{array}{c}7 \\
(3.2)\end{array}$ & $\begin{array}{l}10.6 \\
(4.8)\end{array}$ \\
\hline & 32 & 2 & $\begin{array}{l}15.8 \\
(8.2) \\
\end{array}$ & $\begin{array}{l}23.2 \\
(4.2)\end{array}$ \\
\hline
\end{tabular}

*similar letters shows no statistical difference

**numbers in parentheses indicate standard deviations

In this study, the effects of density $(14,18$, $\left.22,28 \mathrm{~kg} / \mathrm{m}^{3}\right)$ and IFD $(25 \%, 65 \%)$ on IFD loss values of normal foams were considered in the SAS statistical analysis program using the results of IFD loss. Since the interaction between density and the IFD was found statically significant according to SAS results, LSD test was run and LSD value was determined as 5.6, shown in Table 1.

As shown in Table 1, the mean $65 \%$ IFD loss values of the foams with 14 and $18 \mathrm{~kg} / \mathrm{m}^{3}$ densities were statistically greater than the mean $25 \%$ IFD loss values. However, the mean $65 \%$ IFD loss values of the foams with 22 and $28 \mathrm{~kg} / \mathrm{m}^{3}$ densities were not statistically different from the mean loss values of $25 \%$ IFD. As the density raised, the IFD loss ratios decreased. That means the firmness of foam increased. 


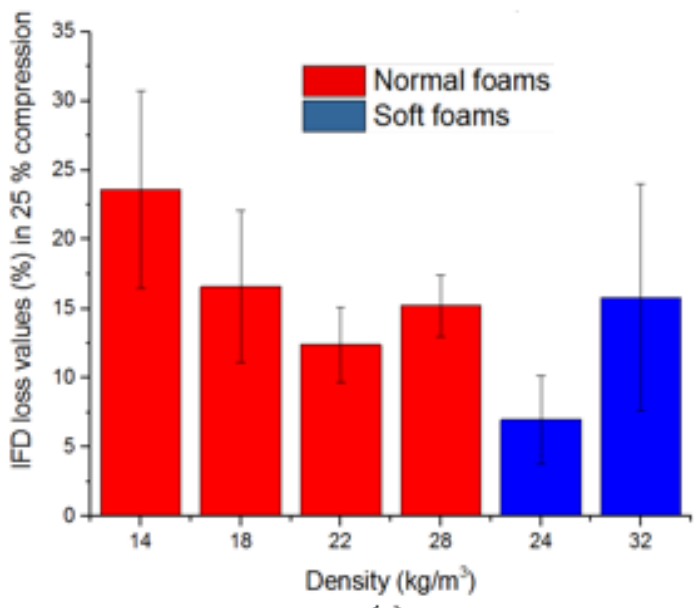

(a)

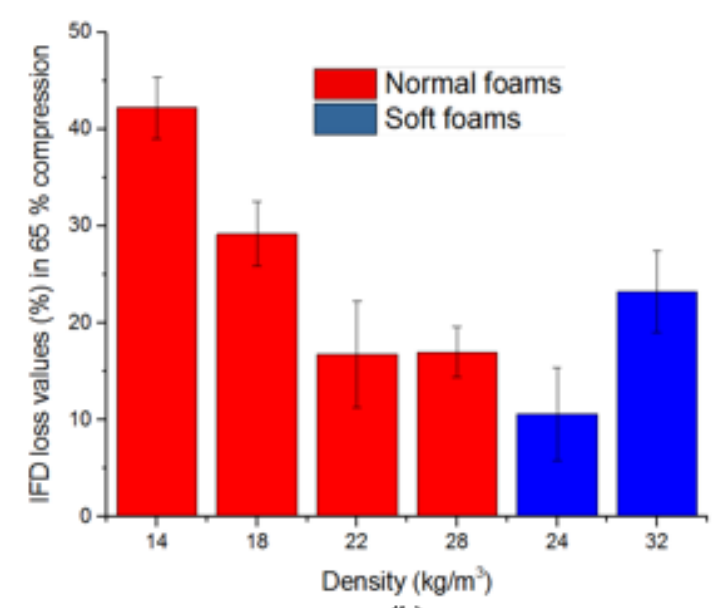

(b)

Figure 6. Comparison of IFD loss values of the foams with different density values at a) $25 \%$ IFD compression b) $65 \%$ IFD compression

As shown in Figure 6, according to initial IFD values in Table 1 , it was observed that as the density increased, the mean $25 \%$ and 65 $\%$ IFD loss values generally decreased in the normal foams. In other words, as the density of the normal foams increased, IFD loss values decreased and the firmness increased at the end of constant-fatigue loading.

Marsavina, Constantinescu, Linul, Voiconi, \& Apostol (2015) studied on shear and fracture properties of PUR foams. They found that increasing foam density increased some shear strength and fracture toughness.

Hager \& Craig (1992) investigated how sitting-foams were failed as a result of constant-fatigue loading. They stated that the reduction in firmness was due to the stresses that occurred during the constant-fatigue loading. In the study, the reason of application of the constant-fatigue loading was shown as generating similar stresses when people sit or stretch on foams by applying a constant loading.

The effects of densities $\left(24,32 \mathrm{~kg} / \mathrm{m}^{3}\right)$ and IFD values $(25 \%, 65 \%)$ on IFD loss values for the soft foams were considered at 5\% significance level in the SAS program. According to the statistic results, the interaction between density and IFD was insignificant, therefore; the LSD analysis was carried out for each main factor. Accordingly, LSD values were 4.9 for the density factor and 3.5 for the IFD factor, respectively.
Table 2. Comparison of densities

\begin{tabular}{|c|c|c|}
\hline \multirow{2}{*}{$\begin{array}{l}\text { Foam } \\
\text { Category }\end{array}$} & \multicolumn{2}{|c|}{ Density $\left(\mathrm{kg} / \mathrm{m}^{3}\right)$} \\
\hline & 24 & 32 \\
\hline Soft & $8.8 \mathrm{~B}$ & $19.5 \mathrm{~A}^{*}$ \\
\hline
\end{tabular}

As shown in Table 2, a significant difference between the density values existed. As density increased, the mean IFD loss also increased for the foams in the soft category. This was opposite with the foams in the normal category because IFD loss values decreased when density of foam increased the normal foams. The soft foam showed an adverse attitude on IFD loss change compared to normal foam. This could be a result of using a softening chemical in soft foam production to have soft foam surface.

As shown in Figure 6, the densities of foams in normal category increased, the IFD loss values decreased and, therefore; firmness of the foams increased while the densities of foams in soft category increased, IFD loss values increased, and therefore; the firmness of the foams decreased. This means that the result observed in the soft foams is contrary to the general opinion, which is increasing density increases firmness in foams. Demirel \& Ergun Tuna (2019) discovered the similar behavior of normal and soft foams in the case of foam density increment after cyclic fatigue loadings. 
Table 3. Comparison of IFD values

\begin{tabular}{lll}
\hline \multirow{2}{*}{$\begin{array}{l}\text { Foam } \\
\text { Category }\end{array}$} & \multicolumn{2}{c}{ IFD Loss After Test } \\
\cline { 2 - 3 } & $25(\%)$ & $65(\%)$ \\
\hline Soft & $11.4 \mathrm{~B}$ & $16.9 \mathrm{~A}^{*}$ \\
\hline
\end{tabular}

In Table 3, IFD loss values for the soft foams subjected to constant-fatigue test are shown. Accordingly, $65 \%$ IFD loss values of soft foams were significantly greater than 25 $\%$ IFD loss values. In other words, the loss values in firmness increased.

\section{Support Factor}

Two of the most common foam evaluation parameters are known as density and 25\% IFD compression (Birlik Sünger, 2013a, 2013b). However, the support factor that helps to see the amount of deeper compression is an also important parameter for foam because an adult sit on a foam deeper than $25 \%$ depth (PFA, 1993). The support factor is also named as the push back factor (Birlik Sünger, 2013b). The mean support factor results for all foams obtained as a result of this study are given in Table 4.

Table 4. Support factor values for all foams

\begin{tabular}{lccc}
\hline & & \multicolumn{2}{c}{ Support Factor } \\
\hline Foam & $\begin{array}{c}\text { Density } \\
\text { Category } \\
\left(\mathrm{kg} / \mathrm{m}^{3}\right)\end{array}$ & \multicolumn{2}{c}{ Constant Fatigue Test } \\
\cline { 2 - 4 } & 14 & Initial & After Test \\
\cline { 2 - 4 } Normal & 18 & 2.1 & 1.59 \\
\cline { 2 - 4 } & 22 & 1.99 & 1.69 \\
\cline { 2 - 4 } & 28 & 1.79 & 1.69 \\
\hline \multirow{2}{*}{ Soft } & 24 & 1.88 & 1.73 \\
\cline { 2 - 4 } & 32 & 1.84 & 1.68 \\
\hline
\end{tabular}

The support factors for foams range from 1.5 to 2.6 (PFA, 2016). In this study, all values are in this range as shown Table 4. In Table 4, the initial support factor values of the normal foams with the densities of 14, 18, 22 and 28 $\mathrm{kg} / \mathrm{m}^{3}$ were $2.1,1.99, \quad 1.79$ and 1.76, respectively. Before constant-fatigue test, the foam with the density of $14 \mathrm{~kg} / \mathrm{m}^{3}$ (lower density) had greater support factor and the foam with the density of $28 \mathrm{~kg} / \mathrm{m}^{3}$ (the greatest density) had the lowest support factor. However, these values were reversed after constant-fatigue loading. Accordingly, the support factor values after constantfatigue loading were $1.59,1.69,1.69,1.73$, respectively, because the more foam density, the more support (PFA, 2016).

Initial support factor values for the soft foams with the densities of 24 and $32 \mathrm{~kg} / \mathrm{m}^{3}$ were 1.88 and 1.84 while final support factor values of them were 1.81 and 1.68. Unlike the normal foams, the soft foams had tendency to have lower support factor values as density increased.

\section{Failure Mode}

A thickness loss of less than $10 \%$ occurred in all of the foams after constant-fatigue loading, but no visual failure was detected on them.

\section{Conclusions}

In this study, the foams groups consisting of 5 replications each and 6 different densities of $14,18,22,24,28,32 \mathrm{~kg} / \mathrm{m}^{3}$ and two different categories of normal and soft were subjected to constant-fatigue loading, and the changes in their IFD and thickness values were evaluated.

Result of constant-fatigue test showed that IFD loss value decreased when density increased for foams in normal category. An increment in density leaded to a reduction in IFD loss rates and an increment in firmness loss. Considering the soft foams after constant-fatigue loading, it was observed that IFD loss values of soft foam increased by increasing foam density on the contrary of the normal foams. Consequently, the relationship between density and firmness is linear for normal foams, but it is inverse for soft foams. At the end of all these evaluations, it is important to note that the $25 \%$ IFD is a primary measurement compared to $65 \%$ IFD measurement and, the 65\% IFD firmness measurement is more used to determine the foam support or support factor.

As density increased, the support factors for normal foams increased but it decreased for soft foams after constant-fatigue loading.

All normal and soft foams used in this study were subjected a thickness loss of less than $10 \%$ after constant-fatigue loading, but no visual failure was detected on the appearances of them. 


\section{Acknowledgement}

We would like to thank the Scientific and Technological Research Council of Turkey (TÜBİTAK) who financially supported this study with the grant number of TOVAG$215 \mathrm{O} 254$ and Gündoğdu Furniture Factory who provided PUR foams to be tested.

\section{References}

ADMET. Announcement dedicated foam testing systems for ASTM D3574. (n.d.) Retrieved from http://www.admet.com/admetannounces-dedicated-foam-testing-systemsfor-astm-d3574/

AFPF (Alliance for Flexible Polyurethane Foam) The furniture industry's guide to today's flexible foam. (1996). Retrieved from http://polyurethane.americanchemistry.com/R esources-and-Document-Library/3810.pdf

Aliha, M.R.M., Linul, E., Bahmani, A. \& Marsavina, L. (2018). Experimental and theoretical fracture toughness investigation of PUR foams under mixed mode I+III loading. Polymer Testing, 67, 75-83.

ASTM D3574 (2011). Standard test methods for flexible cellular materials - Slab, bonded, and molded urethane foams, ASTM International, West Conshohocken, PA

A2LA (American Association for Laboratory Accreditation). Huntsman Polyurethanes. (n.d.) Retrieved from http://www.huntsman.com/polyurethanes/Med ia\%20Library/a_MC1CD1F5AB7BB1738E04 0EBCD2B6B01F1/Customer\%20Service_MC 1CD1F5B56BE1738E040EBCD2B6B01F1/fi les/cust_serv_certs_0290.04.pdf

Birlik Sunger. Yoğunluk. (2013a). Retrieved from http://www.birliksunger.com/sayfa.php?kat=5 \&id=5

Birlik Sunger. Sertlik (ILD, CLD). (2013b). Retrieved from http://www.birliksunger.com/sayfa.php?kat=5 \&id $=4$

Cooperative Extension Furniture, Selecting Upholstered Furniture. (n.d.) Retrieved from http://www2.ca.uky.edu/hes/fcs/factshts/hflra.130.pdf/, 2015 (accessed 08.05.15).

DDL Tested and proven, Independent Testing Laboratory. (n.d.) Retrieved from https://www.testedandproven.com/materialstesting/polyurethane-foam-testing/

De Mello, D., Pezzin, S.H. \& Amico, S.C. (2009). The effect of post-consumer PET particles on the performance of flexible polyurethane foams. Polymer Testing, 28(7), 702-708.

Demirel, S. \& Ergun Tuna, B. (2019). Evaluation of the cyclic fatigue performance of polyurethane foam in different density and category. Polymer Testing. 76, 146-153.

Eckelman, C.A. (1988a). Performance testing of furniture. Part I. underlying concepts. Forest Products Journal, 38(3), 44-48.

Eckelman, C.A. (1988b). Performance testing of furniture. Part II. A multipurpose universal structural performance test method. Forest Products Journal, 38(4), 13-18.

Gama, N., Silva, R., Carvalho, A. P. O., Ferreira, A. \& Barros-Timmons, A. (2017). Sound absorption properties of polyurethane foams derived from crude glycerol and liquefied coffee grounds polyol, Polymer Testing, 62, 13-22.

Gok, A., Yapıcı, F., Gulsoy, S.K., Kurt, S., Altun, S., Kilınç, I. \& Korkmaz, M. (2012). Determination of static fatigue performance of upholstery foams. Kastamonu University Journal of Forestry Faculty, 12(2), 285-290.

Hager, S.L. \& Craig, T.A. (1992) Fatigue testing of high performance flexible polyurethane foam. J. Cell. Plast., 28(3), 284-303.

$\mathrm{Hu}$, L., Tackett, B., Tor, O. \& Zhang, J. (2016). Analysis of sitting forces on stationary chairs for daily activities. Ergonomics. 59(4), 556-567.

IDM instruments, MiniFlx CLD. (n.d.) Retrieved from

http://www.idminstruments.com.au/products/ miniflexcld/

Kumar, M. \& Kaur, R. (2017). Glass fiber reinforced rigid polyurethane foam: synthesis and characterization, e-Polymers, 17(6), 517.

Knight, J.E. (1987). SPI study-Flexible foam inuse fatigue testing for chairs. Journal of Cellular. Plastics, 23(2), 135-157.

Lal, J.A. \& Raman, J. (1992). Polyurethane furniture, toxic gases. Retrieved from http://ir.canterbury.ac.nz/bitstream/10092/847 7/1/lal_raman_report.pdf

Li, A., Yang, D.D., Li, H.N., Jiang, C.L. \& Liang, J.Z. (2018). Flame-retardant and mechanical properties of rigid polyurethane foam/MRP/mg(OH)2/GF/HGB composites. Journal of Applied Polymer Science, 135(31), $1-8$.

Marsavina, L., Constantinescu, D. M., Linul, E., Voiconi, T. \& Apostol, D. A. (2015). Shear and mode II fracture of PUR foams. Engineering Failure Analysis, 58, 465-476.

PFA (Polyurethane Foam Association). In touch: Flexible polyurethane foam: A primer. (2016). Retrieved

from http://pfa.org/intouch/new_pdf/IntouchV1.1a. pdf 
PFA (Polyurethane Foam Association). In touch: How foam firmness affects performance. (1994). Retrieved from http://www.pfa.org/intouch/new_pdf/lr_Intouc hV4.3.pdf

PFA (Polyurethane Foam Association). In touch: Compression modulus (support factor). (1993). http://pfa.org/intouch/new_pdf/lr_IntouchV3. 1.pdf

Saha, M.C., Mahfuz, H., Chakravarty, U.K., Uddin, M., Kabir, Md. E. \& Jeelani, S. (2005). Effect of density, microstructure, and strain rate on compression behavior of polymeric foams. Material Science and Engineering, 406, 328-336.

Standard Council of Canada, Insulating materials. (n.d.) Retrieved from http://palcan.scc.ca/specs/pdf/360_e.pdf

Testresources, ASTM D3574 Testing equipment for flexible cellular urethane foams. (n.d.) retrieved

from http://www.testresources.net/applications/stan dards/astm/astm-d3574-testing-for-slabbonded-and-molded-flexible-cellularurethane-foams/

Todd, B.A., Smith, S.L. \& Vongpaseuth, T. (1998). Polyurethane foams: Effects of specimen size when determining cushioning stiffness. J. Rehabil. Res. Dev., 35(2), 219-224.

Zwick Roel, Soft foam material tests. (n.d.) Retrieved from http://www.zwick.com.tr/tr/uygulamalar/plasti kler/suengerler.html 